\title{
FUNCTIONAL NATURE OF LEGAL MEANS IN THE IMPLEMENTATION OF SOCIAL FACILITIES OF LABOR LAW
}

Kostyuchenko O. Y., Kolesnik T. V.

\section{INTRODUCTION}

Law as a state is an integral component of social development, social transformation, and a necessary tool for ensuring law, freedom and justice ${ }^{1}$. The evolution of social life, the development of market economy, the emergence of new types of relations inevitably affected their legal regulation. There have changed the priorities of legal regulation and a circle of social relations that require legal influence. This requires the search for a modern legal science and the justification of new ways of ensuring the effectiveness of law and means of legal influence on the participants in the legal relationship. In this direction, in our opinion, it deserves attention the instrumental theory of S.S. Alexeyev, whose work was initiated in $1987^{2}$. Determining the methodological foundations for the formation and the use of legal means has a great practical importance for the effectiveness of legislation, the effectiveness of which reflects the level of protection of the rights and freedoms of citizens in the state.

Legal regulation should ensure a "fair balance" of the interests of participants in the area of work. The consolidation, implementation, guarantee, security and protection of rights and freedoms of persons and their groups, in particular in the area of work, must reflect a "reasonable proportion between the used means and the achievable goals". And therefore the law with all legal means must balance the common interest of society, and rights and legitimate interests of the state, employers and workers in the area of work. The globalization of the world and the surge of global and local financial crises inevitably affect the level of well-being of the working population and the provision of working conditions for workers, and thus, overcoming these negative consequences in the area of work without the participation of researchers is impossible. In our opinion, sciencebased approaches to securing the labor rights and legal interests of citizens

1 Шевченко А.С., Ситник О.М. Правова (конституційна) ідеологія як важлива складова державноправового розвитку України (стаття 1). Трипільська цุивілізація. 2012. Т. № 7. С. 19.

2 Алексеев С.С. Правовые средства: постановка проблемы, понятие, классификация. Сов. государство и право. 1987. № 6. С. 12-19.

3 Федоренко проти України: Рішення Європ. суду з прав людини від 01.06.2006. URL: http://zakon3.rada.gov.ua/laws/show/974_041. 
(workers) through legal means can have a positive effect on overcoming the poverty problem of Ukrainians and impoverishment of the working population, where the leading place in the security and protection of labor rights of workers belongs to labor law.

With the purpose to ensure the completeness of the analysis of instrumental theory in the law, it should be noted that the problem of legal means has long been studied in the science of law. The following researchers such as D.A. Andreev ${ }^{4}$, M.V. Volkova 5 , V.T. Komziuk ${ }^{6}$, O.A. Kutsiy ${ }^{7}$, O.V. Malko ${ }^{8}$, M.I. Matuzov ${ }^{9}$, E.B. Olkhovskiy ${ }^{10}$, O.V. Onufrienko ${ }^{11}$, V.A. Sapun ${ }^{12}$, K.V. Shundikov ${ }^{13}$ and others. We also join in the scientific debate on legal means in law.

\section{Instrumental approach to defining legal opportunities in law}

The investigation of legal means is inextricably linked to the mechanism of legal regulation; this statement is based on the proven belief that the generalized concept of a mechanism of legal regulation is defined as a united system of legal means. Through them, it is ensured a productive legal influence on social relations ${ }^{14}$. The purpose of this approach to the research of legal means is a definition of such means and their characteristics.

4 Андреєв Д.О. Адміністративно-правові засоби захисту прав власників цінних паперів : автореф. дис. на здобуття наук. ступеня канд. юрид. наук : спец. 12.00. 07. Київ, 2008. 22 с.

5 Волкова М.В. Правовые средства обеспечения прав и свобод человека: теоретико-правовой анализ : дис. ... канд. юр. наук : спец. 12.00.01. Краснодар, 2010. 205 с.

6 Комзюк В.Т. Адміністративно-правові засоби здійснення митної справи : дис. .. канд. юр. наук : спец. 12.00.07. Харків, 2003. 191 с.

7 Куций О.А. Адміністративно-правові засоби забезпечення прав фізичних осіб у податкових правовідносинах: дис. .. канд. юр. наук : спец. 12.00.07. Одеса, 2004. 192 с.

8 Большой юридический словарь / Авт. кол.: А.В. Малько, К.Е. Игнатенкова, Г.Н. Комкова и др.; Под ред. А.В. Малько. Москва : Проспект. 2009. 704 с.; Теория государства и права: курс лекций / под. ред. А.В. Малько, Н.И. Матузов. 2-е изд., перероб. и доп. Москва : Юристь, 2001. 776 с.

9 Теория государства и права: курс лекций / под. ред. А.В. Малько, Н.И. Матузов. 2-е изд., перероб. и доп. Москва : Юристъ, 2001. 776 с.

10 Ольховський Є.Б. Адміністративно-правові засоби забезпечення громадської безпеки в Україні : автореф. дис. на здобуття наук. ступеня канд. юрид. наук спец : 12.00.07. Харків, 2004. $17 \mathrm{c}$.

11 Онуфрієнко О.В. Правові засоби у контексті інструментальної теорії права : дис. ... канд. юр. наук : спец. 12.00.01. Харків, 2004. 196 с.

12 Сапун В.А. Теория правовых средств и механизм реализации права : дис. ... д-ра юрид. наук : 12.00.01. Нижний Новгород, 2002. 321 с.

13 Шундиков К.В. Цели и средства в праве (общетеоретический аспект) : дис. ... канд. юр. наук : спец. 12.00.01. Саратов, 1999. 182 с.

14 Алексеев С.С. Общая теория права : ученик. 2-е изд., перераб. и доп. Москва : ТК Велби, Проспект, 2008. С. 267. 
The rule of law. Speaking about the rule of law, it is necessary to clearly distinguish the legal norm as a common rule of conduct, which is built on the typical structure in the unity of its elements - a hypothesis, a disposition, a sanction, which S.S. Alexeyev called "a logical norm"15 and the norms that are in the articles of legal acts. Investigating the normative basis as an element of the mechanism of legal regulation, S.S. Alexeyev wrote that the initial source of the mechanism of legal regulation created the legal norms... They have a number of features that allows them to be used as a "regulator" of social relations... with the help of legal norms it is achieved the unity of state regulation... The regulatory regulation of social relations is the determining link in the mechanism of legal regulation. All other links (except the legal consciousness and legal culture...) are not only conditioned by the system of legal norms, creating the law, but in essence, it is its concrete expression. The author emphasizes that the right is a regulator of social relations in the unity, in the system of their norms ${ }^{16}$. It gives a reason to believe that the norm of law is a legal mean (instrument) for regulation of social relations, which regulates the socially meaningful relations.

Having investigated the legal acts as a link of mechanism of legal regulation that serves its normative basis, S.S. Alexeyev notes that such "service" role is inherent legal acts, to which, in addition to normative one the individual acts also belong ${ }^{17}$. The author writes that the condition of effective influence of legal acts on social relations is the form perfection of their expression, which is achieved through the legal technique. It cannot be ignored the emphasis of S.S. Alexeyev on legal technique, as a way of development, processing and systematization of legal acts ${ }^{18}$. But in the articles of legal acts the norm of law is reflected as a norm-statement that is formulated in the form of an external form of law. Misunderstanding of the meaning of the logical norm of law and its incomplete reflection in legal acts, as a result of human activity, sometimes reduces the goal of legal regulation.

Such problem arises when at least one element of the rule of law is absent, which unfortunately often happens in domestic legislation. The problem of the presentation of normative material in the legislation of Ukraine, despite the progressiveness of legislation, which regulates the labor

15 Алексеев С.С. Общая теория права : ученик. 2-е изд., перераб. и доп. Москва : ТК Велби, Проспект, 2008, с. 305.

16 Алексеев С.С. Механизм правового регулирования в социалистическом государстве. Москва : Юрид. лит., 1966. С. 106, 108, 110, 113, 115.

17 Ibid, c. 119.

18 Алексеев С.С. Механизм правового регулирования в социалистическом государстве. Москва : Юрид. лит., 1966. С. 125. 
relations and relations, is closely related to the labor ones. The ways and methods of presentation of normative material do not prove to be effective regulation. The problem of the effectiveness of legal regulation and the use of legal techniques in a certain part begins with the work on bills. We are aware of the fact that the bills are not the norms of law, but we think it is necessary to focus on them, because broadly considering the essence of "legal means", we can refer the bills to legal instruments. Undoubtedly, the number of bills exceeds the number of passed laws, but exactly in these documents, there is fixed the prospects of the occurrence or development, changes and termination of certain legal relationships.

The role of bills in determining the directions of legal regulation with the possibilities of public discussion of their content makes it possible to orientate not only in issues that require the attention of scientists, but also in the variability of the solution of certain problems in the regulation of social relations. At the same time, at the stage of registering the bill, the executive authorities start to implement the statutory competence. These are the powers of the Ministry of Justice of Ukraine, which for each draft law makes a conclusion on its compliance with the current legislation; existing conflicts with acting normative acts; incorrect, false or contradictory interpretation of legal phenomena; coherence of articles of the document etc. Such work of the Ministry of Justice is inextricably linked with the development of legal opinion. Therefore, from the standpoint of scientific expediency, we are defined the draft laws as a legal means of ensuring the implementation of social relations. The draft laws are not only the results of the subjects' activities with the right of legislative initiative, but they also are scientifically substantiated results of scientific research that are aimed at solving practical problems concerning the implementation and protection of the rights and freedoms of citizens in Ukraine. Thus, summing up the above, we note that the draft of law as a normative act is a legal means fulfilling its "official" role providing the perfection of its form and content.

The relationship, according to S.S. Alexeyev, is the main means by which the legal norms are enforced. Relationship is a means of "transition" of general rules of the legal norm into the plane of subjective legal rights and obligations ${ }^{19}$. Investigating the legal relationship, the scientist substantiated three types of legal relationships:

1) general regulatory ones, which are aimed at consolidating the circle of subjects of law and their general legal status;

\footnotetext{
19 Алексеев С.С. Механизм правового регулирования в социалистическом государстве. Москва : Юрид. лит., 1966. С. 130-131.
} 
2) specifically regulatory ones, they are aimed at consolidating the concrete behaviour of subjects;

3) guard relationships, they are aimed at implementing measures of state-compulsory influence ${ }^{20}$.

Agreeing with the author, we note that classification of legal relationships into groups gives the opportunity to direct the scientific search for tools into directions. Namely: 1) instruments that establish the legal status of the subjects of law; 2) legal means of regulating the behaviour of participants in legal relationships; 3) legal instruments of protection and protection of rights.

Individual acts, according to S.S. Alexeyev, are essential in the mechanism of legal regulation. They perform various functions:

(a) individual acts-regulators, along with normative acts, ensure the completeness and comprehensive regulation of social relations;

(b) law enforcement acts are acts of competent authorities issued primarily based on procedural law. Their main function is the implementation of regulatory legal acts;

(c) acts of compliance and use (performance). Use is the process of legal regulation, which ends with the actual realization by the participant of legal relationship of subjective rights and legal obligations. According to the author, the action of the mechanism of legal regulation ends with their implementation. Compliance acts have an independent value, mainly in the implementation of legal relationships active type ${ }^{21}$.

Methodologically important is to separate the individual acts. Such delimitation makes it possible not only to comprehensively cover the regulation of social relations, but also to track the implementation of legal relationships from their occurrence to termination. From the standpoint of the instrumental approach, each stage of the implementation of legal relationships (emergence, change and termination) should have the specific legal means for the implementation of compliance, execution (use) of the legislative requirements.

Legal awareness and legal culture are important elements of the legal regulation mechanism. Legal awareness, above all, is essential for the basis of legal regulation-legal norms. Legal culture, as well as legal consciousness, acts as a means of ensuring the right to act on the stage of realization of subjective rights and obligations ${ }^{22}$.

\footnotetext{
20 Алексеев С.С. Механизм правового регулирования в социалистическом государстве. Москва : Юрид. лит., 1966. С. 140.

21 Алексеев С.С. Механизм правового регулирования в социалистическом государстве. Москва : Юрид. лит., 1966. С. 155-156; 165, 167, 171-172.

22 Ibid, c. 174, 177.
} 
In general, it can be argued that legal culture, as well as legal awareness, is the basic parameter (indicator) of activities of people in public life regarding the observance, use (implementation) of mandatory rules of conduct. These elements of mechanism of legal regulation are close connected with the law and provide voluntary actions of participants of public relations. From the point of view of providing the proper realization of the rights and obligations of participants of legal relations, legal consciousness and legal culture encourage the subjects to the conscious use of the norms of law in their activities. However, in our opinion, these elements cannot be provided with legal instruments. The process of formation of legal consciousness and legal culture does not stand as an object of legal regulation.

Developing own scientific achievements in the research of the mechanism of legal regulation and taking into account the stages of legal regulation, S.S. Alexeyev sorted out four main elements of the mechanism of legal regulation: legal norms, individual requirements for the use of law (optional element), legal relationships, acts of realization of rights and obligations ${ }^{23}$. However, the research of the scientist is not limited to the definition of mechanism's elements of legal regulation and its characteristics. He had consistently scientifically substantiated the various approaches to it, in particular, instrumental and special legal, psychological aspects ${ }^{24}$. Taking as a basis position of S.S. Alexeyev about the mechanism of legal regulation and its various aspects, we consider the instrumental approach as very important, that can cover all means and legal instruments in the process of proper legal regulation of legal relations. It should be noted that such approach is useful, taking into account that a significant part of the relations, in particular, in the labor regulation, is transformed or arisen in Ukraine (for example, social partnership relations are being renewed, outstaffing agreements are being developed, and atypical forms of employment are arising). In order to ensure an adequate regulation of such relationships, it is necessary to determine which legal means can be used to achieve the main practical purpose of regulation - the realization and protection of the rights and freedoms of citizens, business entities and the state.

S.S. Alexeyev's instrumental approach to the mechanism of legal regulation is based on the fact that:

${ }_{23}$ Алексеев С.С. Общая теория права : учебник. 2-е изд., перераб. и доп. Москва : ТК Велби, Проспект, 2008. С. 282. Алексеев С.С. Общая теория права : в 2 т. Т. ІІ. Москва : Юрид. лит., 1982. С. 27.

24 Алексеев С.С. Общая теория права : ученик. 2-е изд., перераб. и доп. Москва : ТК Велби, Проспект, 2008. С. 267-279. Алексеев С.С. Общая теория права : в 2 т. Т. ІІ. Москва : Юрид. лит., 1982. С. 9-24. 
(a) legal means is the most general, universal category ${ }^{25}$;

(b) in general, the legal means in the field of legal regulation can be presented as a kind of "trinity" with primary importance: prohibition, positive commitment, permission. All other legal means, as the author emphasized, are a modification or combination of means of legal regulation ${ }^{26}$;

(c) the development of society is complicated by the composition and content of legal means... The most significant of these processes are two. Firstly, it is a classification of legal means. With their help, the legal constructs and the system structural units began to emerge. Secondly, the legal means (both at the primary and at the level of legal structures, structural units) acquire a normative nature ${ }^{27}$.

S.S. Alexeyev pointed out that the issue of legal means is not the issue of assigning to a special unit of certain fragments of legal reality, but the issue of their particular vision in a strictly defined perspective - their functional purpose, their role as instruments of optimal solution of social problems. The author stressed that in all cases, there are fragments of legal reality before us, which can be considered due to their functions and the role as tools of legal influence ${ }^{28}$. In our opinion, this indicates that the legal means ensure the functioning of the mechanism of legal regulation, where the regulation of social relations is a manifestation of the State's will. The decision of the state of social tasks should be reflected not only in the norms of prescriptions, but also to be ensured by the specific legal constructions of the implementation of state will. The objectification of such realization "lives" in the process of emergence, change and termination of legal relations.

Investigating the "whole" matter of law, S.S. Alexeyev concluded that the "trinity" (i.e. prohibition, positive commitment and permission) show themselves as the delimitation of branches of law... The legal specificity

\footnotetext{
25 Алексеев С.С. Право на пороге нового тысячелетия: Некоторые тенденции мирового правового развития - надежда и драма современной епохи. Москва : Статут, 2000. С. 31. Алексеев С.С. Собрание сочинений: в 10 т. (+Справоч. том). Т. 5 : Линия права. Отдельные проблемы концепции. Москва : Статут, 2010. С. 323.

26 Алексеев С.С. Право на пороге нового тысячелетия: Некоторые тенденции мирового правового развития - надежда и драма современной епохи. Москва : Статут, 2000. С. 32. Алексеев С.С. Собрание сочинений: в 10 т. (+Справоч. том). Т. 5 : Линия права. Отдельные проблемы концепции. Москва : Статут, 2010. С. 324.

27 Алексеев С.С. Право на пороге нового тысячелетия: Некоторые тенденции мирового правового развития - надежда и драма современной епохи. Москва : Статут, 2000. С. 33, 35. Алексеев С.С. Собрание сочинений: в 10 т. (+Справоч. том). Т. 5 : Линия права. Отдельные проблемы концепции. Москва : Статут, 2010. С. 326-327.
}

28 Алексеев С.С. Теория права. Москва : БЕК, 1993. С. 218, 223. 
of branches which is characterized with their mode and regulatory methods caused by that whether they have an obligatory, prohibitive or permissive direction ${ }^{29}$. It is important, in our opinion, that the author of the instrumental theory will emphasize in his works the starting points from which the formation of legal instruments begins. Besides the legal means of primary importance, the scientist directs our efforts to search for legal instruments and for "the main thing, "the structure" (construction, organization) of legal regulation" 30 . Recognizing the sectoral peculiarity of legal means, S.S. Alexeyev focuses our attention not on the formalized statement of the list of legal means, but motivates us to a new point of view of the right, that means its matter. Determining the mechanism of legal regulation, as the unity of the system of legal means, the author examined this system by enriching it with specific legal means without restricting scientific searches to only universal means or an exhaustive list of legal instruments.

\section{The practical value research of legal means}

The practical value of S.S. Alexeyev's theory consist in the fact that in the research of legal means, the theory of law serves as the basis for further practical and applied researches. At the same time, from the standpoint of the sectoral use of legal means that are developed in the theory of law, their peculiarity consists in the universality of tools that ensure the implementation of certain legal relations. This relates (according to the classification of S.S. Alexeyev) both as to legal means of primary importance, as well as modified or combined legal regulation. However, the modification and combination of legal means for regulation of specific legal relationships should be based on the theory of law and reflect the sectoral peculiarity of legal influence on the participants of legal relations, where the sectoral originality is a key criterion that determinately influences the set and content of legal means. They are inherent in one or another branch of law.

For the research of our opinion, we give the conclusion of S.S. Alexeyev about the content of the sciences, which affect the economic and social spheres of life. The author wrote that the point of focusing of worked

\footnotetext{
29 Алексеев С.С. Собрание сочинений: в 10 т. (+ Справоч. том). Т. 4: Линия права. Концепция: Сочинения 1990-х - 2009 годов. Москва : Статут, 2010. С. 215. Алексеев С.С. Тайна и сила права. Наука права: подходы и идеи. Право в жизни и судьбе людей. 2-е изд., перераб. и доп. Москва : Норма, 2009. С. 36.

30 Алексеев С.С. Собрание сочинений: в 10 т. (+ Справоч. том). Т. 4: Линия права. Концепция: Сочинения 1990-х - 2009 годов. Москва : Статут, 2010. С. 216. Алексеев С.С. Тайна и сила права. Наука права: подходы и идеи. Право в жизни и судьбе людей. 2-е изд., перераб. и доп. Москва : Норма, 2009. С. 38.
} 
constructive tools for solving economic and social problems is not economic disciplines (as it commonly believed), but legal ones - i.e. jurisprudence ${ }^{31}$. We assume that this problem statement about the concentration of tools contradicts the realities of today. The practice proves that the solution of economic and social problems cannot be based on the priority of one particular science. The interdisciplinary approach, in our opinion, is more acceptable. For example, combination of economic and legal instruments of providing the workers' labor rights should create a positive synergistic effect for achievement the general socially important goal, that means for providing and maintaining the rule of law in the labor sphere.

As S.S. Alexeyev rightly pointed out, the formation of legal structures in one or another national legal system occurs in many cases spontaneously, during complicated practical relations and it represents rather a long process, which ... has ... formalized, by the way, quite often, complicated formalized character, which largely reveals the technology of formation of legal constructions ${ }^{32}$. This proves the necessity of working out a number of legal constructions as legal models of regulation of different legal relations. But such work requires time, scientific approach and approbation of these models in practice with the further implementation into law enforcement activities.

As the author of the instrumental theory, S.S. Alexeyev noted the development of legal constructions is mainly the merit of legal dogma, analytical jurisprudence, and mainly in the branch of legal disciplines... An analysis of group of legal norms, principles and legal relationships that belong to this category of legal cases, as a rule, represents identification and processing of peculiar legal structure... This is, in essence, the statement, insulation and the formal and logical characteristic of peculiar legal construction - i.e. the type relations of rights, obligations, responsibilities, legal facts ${ }^{33}$. Methodologically important is the emphasis on analytical jurisprudence. This testifies that legal tools cannot be formed only on the background of the practice of using the current legislation. It is a scientific analysis of current problems that requires legal regulation and research of the practice of applying legal acts and it is this material from which it is necessary to isolate and combine the legal structure that will provide the functioning of legal norms and implementation of legal relationships.

\footnotetext{
31 Алексеев С.С. Линия права. Москва : Статут, 2006. С. 220-221.

32 Ibid, c. 212.

33 Алексеев С.С. Линия права. Москва : Статут, 2006. С. 216.
} 
Regarding the labor law, it should be emphasized that the legal possibilities of labor law are manifested, for example, through such legal means as encouragement and promotion. Their goal is to develop labor relations, to encourage workers and employers to work actively, to stimulate a competitive environment in the labor market, which should result in a high level of protection of interests of the participants in labor relations, and as a consequence, a socio-economic development in the state. The legal influence on the participants in labor relations, which is implemented through promotion and stimulation, should generate the activity in the world of work, and the legal conditions for the realization the rights to work should stimulate in general socio-economic development. Incentives should be considered as the potential of labor law for the sustainable development of labor relations. Government bodies, by issuing the regulations, should clearly track the legal possibilities that are laid down in the regulatory acts for stimulating the labor activity of population, rather than the incentive to expand the shadow labor market in Ukraine.

Thus, as a result, it should be noted that the instrumental theory, which is used to solve the problem of consolidating, implementing, guaranteeing, securing and protecting labor rights, freedoms and legitimate interests of citizens and their groups, makes it possible to approve the scientific results of theoretical and industry research with a goal to distinguish the legal means in the labor law of Ukraine. This approach to solving legal problems in labor law is a new legal knowledge that hastens the right to practical application in the issue of controlled management of processes in the labor sphere, in particular, regarding the providing of adequate and safe conditions of work, stability of labor relations, stimulation of conscientious and productive labor, etc. It is important that the use of such combined means as an encouragement and incentives for influencing all relations in the area of work is charged with the social and economic results of working life, both for the participants in the labor relations and for the state.

The investigated theory of S.S. Alexeyev is the basis for the science of labor law in the search for new ones and a combination of existing legal means. Also, the allocation of updated legal means of influence on the participants in labor relations should provide the protection of employees' rights as an economically weak side of work agreement. The analysis of law regulation based on "idea of legal means" enriches methodologically a new approach to solving the current problems in the world of work. It is characterized the practical value of legal means that specifies the necessity for further development of instrumental theory in labor law. This theory 
fulfils a functional purpose reflecting the peculiarities of legal instruments, revealing the legal possibilities in the legal matter, which eventually should ensure the implementation of social function of labor law.

\section{Functional approach to the legal support of labor rights}

The abovementioned gives reason to delve into the peculiarities of legal means in labor law, which can be represented as follows ${ }^{34}$ :

1. The combination of private and public nature, which is determined by the rules of labor law what is inherent to legal tools in labor relations.

2. The legal means in labor law direct their regulatory influence on the achievement of goals that have socio-economic, industrial, organizational and educational nature. It is the aims of the legal regulation of non-self-employment on the basis of work agreement that are decisive for the classification of legal means of labor law and affect their size and variability.

3. These means are active (working) parts of the legal reality that "transform" the rules of conduct into the specific factual behavior of the participants in the employment relationship.

4. The tools of labor law are fixed not only by the state, but also by participants of labor relationship (employee and employer) and social partners as participants in the social-partnership relations.

5. The legal significance of the use of legal means in labor law has most a private nature, and their development and multiplicity highlight the specific level of rights realization, freedoms and legal interests of each individual employee and workforces.

This, in its turn, proves the need for the development of instrumental theory in the labor law and the need to systematize the existing legal means by different classification features.

In order to distinguish a set of combined and modified legal means in labor law, the following should be considered:

- first, work as an object of work relations has its own characteristics, however, taking into account that legal science cannot contradict itself in a broad sense, the choice of legal means in work relations should not "conflict" with the primary significance trinity (authorization, prohibition, obligation);

- secondly, there is no need immediately to identify all possible legal tools that contribute to the realization of the rights of participants

34 Костюченко О.Є. Реалізація соціального призначення трудового права в Україні : монографія. Харків : Право, 2018. С. 123-124. 
in work relationships, because science and social life are not static, they are developing, which makes it impossible in a single study to identify and characterize all legal means of implementing the social purpose of labor law. As S.S. Alekseyev rightly pointed out, the formation of legal constructs in one or another national legal system occurs in many cases spontaneously, in the course of complex practical relations, and is a rather long process, which has a formalized, incidentally, often complicated formalized nature, that largely reveals the technology of forming legal constructs ${ }^{35}$. This proves the need to develop a number of legal constructs, including legal models in the area of work. However, this work takes time, scientific approach, and approbation of such models in practice with further implementation;

- thirdly, within any theory, even the most grounded, due to its unification, a number of specific features are lost, which are characterized a certain field of law features and legal means. However, it does not diminish the theoretical and practical value of the instrumental theory in the theory of law. Thus, having developed a legal toolkit based on the theory of S.S. Alekseyev, it is impossible to limit the research to a set of legal means defined by the theorists of law. Sectoral identity of labor relations, although it narrows the set of legal means, but the content of such legal means is specific in relation to the problem of ensuring the implementation of social purpose of labor law and the goals achievement of legal labor regulation. According to S.S. Alekseyev, the development of legal construct is mainly a merit of legal dogma, analytical jurisprudence, and mostly specific sectoral legal disciplines. Analysis of a group of legal norms, principles and legal relationships that belong to this category of legal cases, as a rule, represent the development of a specific legal construct. In essence, this is a statement, separation and formal-logical characteristic of a peculiar legal construct a typical relation between rights, obligations, responsibilities, and legal facts ${ }^{36}$;

- fourth, legal means of labor law must ensure achievements of its purpose and objectives as a social law within the framework of labor law norms based on freedom, equality and justice. At the same time, the legal tools that ensure the realization of the social purpose of labor law in Ukraine must give effect to its principles, namely: the rule of law; the priority of contractual means in solving conflicts; timeliness and adequacy of measures to protect legal rights and interests; unity and differentiation of legal regulation of labor, etc.;

\footnotetext{
35 Алексеев С.С. Собрание сочинений: в 10 т. (+ Справоч. том). Т. 4: Линия права. Концепция: Сочинения 1990-х - 2009 годов. Москва : Статут, 2010. С. 221; Алексеев С.С. Линия права. Москва : Статут, 2006. С. 212.

36 Алексеев С.С. Линия права. Москва : Статут, 2006. С. 216.
} 
- fifth, it should be noticed that the practical use of legal tools (instruments) will be carried out not only by specialists in the field of law, but also by specialists of other professions, which proves the need not only to the theoretically substantiate the use of this tool, but to isolate specific a set of legal means for their further use in practice. Ultimately, this fact poses another practical task for researchers - to direct the theoretical debate about legal means in labor law into the plane of their practical use, providing these means with specific content, and to isolate a number of legal models of solving key problems in the direction of the social purpose of labor law.

Bringing the state of realization of the social purpose of labor law in Ukraine to the required (desired) level - freedom, equality and justice should be enshrined in legal norms, which gives a normative nature to socially significant goals in labor relations and is achieved by means of the "trinity" of legal means, such as permission, prohibition and positive obligation. These legal means have an informative character and are reflected in the sources of labor law.

By delving into the instrumental theory of law, let us agree that the issue of the legal means by which the goals of legal regulation are attained is decisive in determining its effectiveness. The legal phenomenon, the features of the legal means operate in the relation "purpose - means - result" 37 . Therefore, assuming that the legal possibilities of labor law, manifested in promotion and stimulation, are realized through the rights and obligations of the subjects of labor law, then their aim should be a realization of social facilities of labor law, which makes possible not only the material enrichment of the relevant participants, but also creates the conditions for the moral, spiritual and cultural development of the employee, the main driving force in the production of goods, works and services. The ultimate goal of realization of social facilities of labor law through the implementation in practice of legal opportunities embodied in labor law should be the socioeconomic development of Ukraine. Because the achieved results need to be monitored, we consider it necessary to supplement the above model and propose to present the functional action of sectoral legal means as a model: "purpose - means - result - control". Thus, control should be exercised primarily in order to identify the reasons for the failure to achieve the set goals and, therefore, to adjust modifications and combinations of legal means. In the last turn, the purpose of control should be to prosecute and impose fines to fill the state budget.

37 Проблемы теории государства и права : учебное пособие / под ред. М.Н. Марченко. Москва : Проспект, 1999. С. 321, 322. 
Legal influence on the participants in the area of labor should provide such opportunities for realization of economic and social interests of subjects that give rise to their activity in general (creation of working places, employment of the population, decent working conditions, decent payment, encouragement to high-productive work, stimulation of conscientious attitude to their duties, etc.). The legal conditions for the implementation of such active actions should stimulate the socio-economic development, cultural and spiritual enrichment of the nation as a whole.

Taking into account that in the instrumental theory in law, the important is that which social tasks these legal mechanisms can solve, where and how they can be used in practical legal activity to achieve socially significant results ${ }^{38}$. Respectively, the socially significant results of the sectoral legal means are the realization of the social purpose of labor law, where the expected result of such legal influence is the sustainable development of labor relations and the realization of the concept of "decent work" in Ukraine.

\section{CONCLUSIONS}

The new socio and economic conditions of Ukraine's development require the revision and updating of the legal framework to ensure the implementation of effective legal constructs, which are capable to satisfy the socio-economic interests of employees with the keeping of reasonable proportion between the used means and the achieved objectives. To solve this practical task, the best one is the instrumental theory, by developing of which in the context of the social purpose of labor law, the orientation of the targeted sectoral legal means acquires specific goals-the consolidation, implementation, guarantee, security and protection of labor rights and socioeconomic interests of the employee. The whole cycle of the mechanism of legal regulation is revealed in the functional purpose of legal tools, and through legal means, it is possible to realize the legal potential of labor law to solve a specific social task. This is precisely what makes labor law means those instruments that embody the power of law and implement the legal possibilities in practice.

The socially significant results of the action of sectoral legal means are the realization of the social facilities of labor law, where the expected result of such legal influence is the sustainable development of labor relations and the realization of the concept of "decent work" in Ukraine. That create

38 Сапун В.А. Инструментальная теория права в юридической науке. Современное государство и право. Вопросы теории и истории : сборник научных трудов. Владивосток, 1992. C. 20. 
their activity in general, and the legal conditions for the implementation of active actions should stimulate the socio-economic development, cultural and spiritual enrichment of the nation as a whole.

Legal means of primary importance - are permission, prohibition, and positive obligation, provide the opportunity in law-making and enforcement activities to develop a series of legal models where the labor rights and the legitimate interests of labor law subjects are implemented in general. In addition, the orientation of legal models for securing, guaranteeing, implementing, and protecting functionally aims them at achieving socially significant goals. The legal means as a tool of action are used to achieve the goals of legal regulation in a context of legal convergence. The sectoral legal means direct their regulatory influence on the achievement of goals that have socio-economic, productive, organizational and educational character. Legal means, as part of legal reality, transform the rules of conduct into concrete, factual behaviour of participants in employment relationships.

\section{SUMMARY}

It is considered the mechanism of legal regulation in the article. There are investigated the fundamental ideas of S.S. Alexeyev about the instrumental theory in law. It is analyzed the proposed division of legal means (instruments). It is determined the practical value of the instrumental approach in labor law. Separately, it is emphasized that such combined legal means as encouragement and incentives are charged with social and economic results of labor activity both for the participants of labor relations and for the state. The analysis of law regulation on the basis of "idea of legal means" enriches methodologically a new approach to solving the urgent problems in the world of work. It is described the practical value of legal means, we indicate the need for further development of instrumental theory in labor law. This theory fulfills a functional purpose reflecting the peculiarities of legal instruments, revealing the legal possibilities in the legal matter, which eventually should ensure the implementation of labor law. It is emphasized that the legal influence on the participants in the relations in the area of labor should provide such opportunities for realization of economic and social interests of the entities. That create their activity in general, and the legal conditions for the implementation of active actions should stimulate the socio-economic development, cultural and spiritual enrichment of the nation as a whole. The socially significant results of the action of sectoral legal means are the realization of the social 
facilities of labor law, where the expected result of such legal influence is the sustainable development of labor relations and the realization of the concept of "decent work" in Ukraine.

\section{REFERENCES}

1. Шевченко А.С., Ситник О.М. Правова (конституційна) ідеологія як важлива складова державноправового розвитку України (стаття 1). Трипільська изивілізація. 2012. Т. № 7. С. 16-21.

2. Алексеев С.С. Правовые средства: постановка проблемы, понятие, классификация. Сов. государство и право. 1987. № 6. С. 12-19.

3. Федоренко проти України: Рішення Європ. суду з прав людини від 01.06.2006. URL: http://zakon3.rada.gov.ua/laws/show/974_041.

4. Андреєв Д.О. Адміністративно-правові засоби захисту прав власників цінних паперів : автореф. дис. на здобуття наук. ступеня канд. юрид. наук : спец. 12.00. 07. Київ, 2008. 22 с.

5. Волкова М.В. Правовые средства обеспечения прав и свобод человека: теоретико-правовой анализ : дис. ... канд. юр. наук : спец. 12.00.01. Краснодар, 2010. 205 с.

6. Комзюк В.Т. Адміністративно-правові засоби здійснення митної справи : дис. ... канд. юр. наук : спец. 12.00.07. Харків, 2003. 191 с.

7. Куций О.А. Адміністративно-правові засоби забезпечення прав фізичних осіб у податкових правовідносинах : дис. ... канд. юр. наук : спец. 12.00.07. Одеса, 2004. 192 с.

8. Большой юридический словарь / Авт. кол.: А.В. Малько, К.Е. Игнатенкова, Г.Н. Комкова и др. ; Под ред. А.В. Малько. Москва : Проспект. 2009. 704 с.

9. Теория государства и права: курс лекций / под. ред. А.В. Малько, Н.И. Матузов. 2-е изд., перероб. и доп. Москва : Юристь, 2001. 776 с.

10. Ольховський Є.Б. Адміністративно-правові засоби забезпечення громадської безпеки в Україні : автореф. дис. на здобуття наук. ступеня канд. юрид. наук : спец. 12.00.07. Харків, 2004. 17 с.

11. Онуфрієнко О.В. Правові засоби у контексті інструментальної теорії права : дис. ... канд. юр. наук : спец. 12.00.01. Харків, 2004. 196 с.

12. Сапун В.А. Теория правовых средств и механизм реализации права : дис. .. д-ра юрид. наук : 12.00.01. Нижний Новгород, 2002. 321 с.

13. Шундиков К.В. Цели и средства в праве (общетеоретический аспект) : дис. ... канд. юр. наук : спец. 12.00.01. Саратов, 1999. 182 с.

14. Алексеев С.С. Общая теория права : учебник. 2-е изд., перераб. и доп. Москва : ТК Велби, Проспект, 2008. 576 с.

15. Алексеев С.С. Механизм правового регулирования в социалистическом государстве. Москва : Юрид. лит., 1966. 187 с. 
16. Алексеев С.С. Общая теория права : в 2 т. Т. II. Москва : Юрид. лит., $1982.360 \mathrm{c}$.

17. Алексеев С.С. Право на пороге нового тысячелетия: Некоторые тенденции мирового правового развития - надежда и драма современной епохи. Москва : Статут, 2000. 256 с.

18. Алексеев С.С. Собрание сочинений: в 10 т. (+Справоч. том). T. 5: Линия права. Отдельные проблемы концепции. Москва: Статут, 2010. 549 c.

19. Алексеев С.С. Теория права. Москва : БЕК, 1993. 224 с.

20. Алексеев С.С. Собрание сочинений: в 10 т. (+ Справоч. том). Т. 4: Линия права. Концепция: Сочинения 1990-х - 2009 годов. Москва : Статут, 2010. 544 c.

21. Алексеев С.С. Тайна и сила права. Наука права: подходы и идеи. Право в жизни и судьбе людей. 2-е изд., перераб. и доп. Москва : Норма, 2009. $176 \mathrm{c}$.

22. Алексеев С.С. Линия права. Москва : Статут, 2006. 461 с.

23. Костюченко О.Є. Реалізація соціального призначення трудового права в Україні : монографія. Харків : Право, 2018. 392 с.

24. Проблемы теории государства и права : учебное пособие / под ред. М.Н. Марченко. Москва : Проспект, 1999. 504 с.

25. Сапун В.А. Инструментальная теория права в юридической науке. Современное государство и право. Вопросы теории и истории : сборник научных трудов. Владивосток, 1992. С. 17-22.

\section{Information about authors:}

Kostyuchenko O. Y.,

Doctor of Law, Associate Professor, Professor of the Department of Civil Law and Process University of the State Fiscal Service of Ukraine 31, Universytetska str., Irpin, Kyiv region, Ukraine

Kolesnik T. V.,

Doctor of Law, Associate Professor, Professor of the Department of Civil Law Disciplines Donetsk Law Institute of Ministry of Internal Affairs of Ukraine 92a, Commonwealth str., Kryvyi Rih, Ukraine

DOI https://doi.org/10.30525/978-9934-588-43-3/2.12 